\title{
The electrophoretic mobility of Gram-negative and Gram-positive bacteria: an electrokinetic analysis
}

\author{
Manfred E. BAyer* and John L. Sloyer, JR \\ Institute for Cancer Research, Fox Chase Cancer Center, 7701 Burholme Avenue, Philadelphia, PA 19111, USA
}

(Received 17 October 1989; revised 3 January 1990; accepted 31 January 1990)

\begin{abstract}
The electrophoretic mobility (EPM) of a variety of Gram-negative and Gram-positive bacteria was measured with a Penkem S3OOO analyser. Under standard growth conditions and neutral pH all cells displayed a negative EPM. The polysaccharide capsules of Escherichia coli strains K1, K5, K29 and K30 generated the highest EPM; to a lesser and varying degree $O$-antigens with charged groups and core lipopolysaccharides also contribute to the net EPM. Very little negative EPM was measured in suspension cultures of the gliding bacterium Cytophaga U67. No difference in the EPM was observed between rapidly growing and stationary-phase $E$. coli B. De-energization of the cell membranes by carbonyl cyanide $m$-chlorophenylhydrazone (CCCP) did not affect the EPM of wild-type and deep rough mutants of $E$. coli; and the EPM of Cytophaga U67 and Acholeplasma laidlawii remained unaltered by CCCP when measured in their respective growth media. Extrusion of filamentous bacteriophage $\mathrm{f} 1$ from cells of its host, $E$. coli A95, caused a shift to a higher negative EPM. We also measured a variety of Grampositive strains, all of which displayed different EPMs. When membrane fractions of $E$. coli were adsorbed to latex spheres, characteristic differences between the EPM of beads coated with either inner or outer membrane were observed. The results suggest that the rapid EPM analysis is-a useful tool to study the net electric charge of microorganisms and to examine changes of surface properties during interaction of cells with viruses, proteins (antibody) and charged antibiotics.
\end{abstract}

\section{Introduction}

The interaction of a cell with its environment begins at the outermost fringes of the cell surface. The physicochemical composition and structural organization of the surface determines subsequent events, which will lead to either adsorption or repulsion of an advancing molecule. The result of these encounters is of great importance to a micro-organism in terms of both a rapid molecular signal transfer and a slower, but longer-lasting adaptation of the cell to its environment. The electrostatic charge of the cell surface is a net charge resulting from the combined charges of the molecules comprising the cell surface and their counter-ions. The charge affects adsorption of ions as well as the rate of uptake of nutrients and antimicrobial drugs. Surface charges are also among the parameters that determine the fate of a bacterial cell when under attack by, for example, bacteriophages or by the molecular and cellular immune defences of the eukaryotic host. Free-living bacteria,

Abbreviations: CCCP, carbonyl cyanide m-chlorophenylhydrazone; EPM, electrophoretic mobility; PMBNP, polymyxin B nonapeptide. including pathogenic organisms, are equipped with a cell envelope containing charged polysaccharides such as capsules, lipopolysaccharides (LPS) and surface proteins.

Several experimental techniques have been used to demonstrate the net charge of individual bacteria and of bacterial populations; in the former case, electron microscopy of positively charged marker molecules suggested a mosaic of anionic surface domains at the cell surface of Salmonella typhimurium (Magnusson \& Bayer, 1982). While this approach allows us to localize a charge with high topological resolution, it is useful only for the study of a limited number of cells. The examination of large populations of micro-organisms requires other methods, such as electrophoresis, in which the electrophoretic mobility (EPM) of charged particles is measured in an externally applied electric field. The direction and rate of this movement depend, among other factors, on the polarity and the density of the particles' net surface charge, the strength of the electric field, the ionic strength, the temperature and the $\mathrm{pH}$ of the medium. The mathematical relationship of these factors has been discussed by Richmond \& Fisher 
Table 1. Bacterial strains, growth conditions and references

\begin{tabular}{|c|c|c|c|}
\hline Strain & Growth medium & $\begin{array}{l}\text { Temperature } \\
\left({ }^{\circ} \mathrm{C}\right)\end{array}$ & $\begin{array}{l}\text { Reference for origin, } \\
\text { characteristics or medium }\end{array}$ \\
\hline Escherichia coli $\mathrm{B}$ & L-medium & 37 & $\begin{array}{l}\text { M. E. Bayer Collection } \\
\text { (origin } 1962 \text { Weidel, Tübingen, FRG) }\end{array}$ \\
\hline E. coli $\mathrm{B}$ & High/low phosphate & 37 & Neu \& Heppel (1965) \\
\hline E. coli $\mathrm{B} / 1,5$ & L-medium & 37 & W. Cramer, Purdue University, IN, USA \\
\hline E. coli $\mathrm{W} 3110$ & L-medium & 37 & Lunn \& Pigiet (1982) \\
\hline E. coli CR34 & Trypticase Soybroth & 35 & Koplow \& Goldfine (1974) \\
\hline E. coli GR467 & Trypticase Soybroth & 35 & Koplow \& Goldfine (1974) \\
\hline Salmonella anatum & L-medium & 37 & LeMinor, Institut Pasteur, Paris, France \\
\hline S. ado & L-medium & 37 & S. Uetake, University of Kyoto, Japan \\
\hline S. typhimurium LT2-M1 & L-medium & 37 & K. Magnusson, University of Linköping, Sweden \\
\hline E. coli A95 & L-medium & $34 / 41 \cdot 5$ & Russell \& Model (1983) \\
\hline E. coli A96 & L-medium & $34 / 41 \cdot 5$ & Russell \& Model (1983) \\
\hline E. coli $\mathrm{K} 1$ (Troy) & L-medium & 37 & $\begin{array}{l}\text { F. A. Troy, University of California, School of } \\
\text { Medicine, Davis, USA }\end{array}$ \\
\hline E. coli $\mathrm{K} 1$ (Bort) capsule-negative mutant & L-medium & 37 & A. Cross, Walter Reed, Washington DC, USA \\
\hline E. coli $09: \mathrm{K} 29$ & L-medium & 37 & H. Stirm, University of Giessen, FRG \\
\hline E. coli $\mathrm{O} 9$; capsule K29-negative mutant & L-medium & 37 & \\
\hline E. coli $\mathrm{O} 9: \mathrm{K} 29$ ts capsule mutant $\mathrm{M} 13$ & L-medium & 34 & Bayer \& Thurow, 1977 \\
\hline E. coli $\mathrm{O} 9: \mathrm{K} 29$ ts capsule mutant $\mathrm{M} 41$ & L-medium & 34 & \\
\hline E. coli $\mathrm{K} 30$ strain; $\mathrm{O} 9: \mathrm{K} 30$ & L-medium & 37 & \\
\hline E. coli $\mathrm{K} 30$ strain; $\mathrm{O} 9$ : capsule-negative mutant & L-medium & 37 & K. Jann, Max Planck Institut \\
\hline $\begin{array}{l}E \text {. coli } \mathrm{K} 30 \text { strain; } \mathrm{O} \text {-antigen-negative } \\
\text { and capsule-negative mutant }\end{array}$ & L-medium & 37 & für Immunbiologie, Freiburg, FRG \\
\hline E. coli $\mathrm{K} 5$ strain $\mathrm{A} 63 ; \mathrm{O} 18: \mathrm{K} 5$ & L-medium & 37 & \\
\hline $\begin{array}{l}E \text {. coli } \mathrm{K} 5 \text { strain } \mathrm{A} 63 ; \mathrm{O} 18 \text {, } \\
\text { capsule-negative mutant }\end{array}$ & L-medium & 37 & \\
\hline E. coli $\mathrm{K} 5$ strain 357 ; O6: $\mathrm{K} 5$ & L-medium & 37 & A. Cross, Walter Reed, Washington, DC, USA \\
\hline $\begin{array}{l}\text { E. coli } \mathrm{K} 5 \text { strain } 357 \text {; } \\
\text { O6, capsule-negative mutant }\end{array}$ & $\mathrm{L}$ medium & 37 & \\
\hline Staphylococcus aureus ATCC 25923 & L-medium & 37 & \\
\hline S. aureus 82 & L-medium & 37 & N. Georgopapadakou, Roche Institute, NJ, USA \\
\hline S. aureus 3037 & L-medium & 37 & \\
\hline Micrococcus luteus & L-medium & 37 & $\begin{array}{l}\text { G. Shockman, Temple University Medical School, } \\
\text { Philadelphia, PA, USA }\end{array}$ \\
\hline Membrane vesicles (derived from CS109) & L-medium & 37 & $\begin{array}{l}\text { E. coli CS109 from C. Schnaitman, University of } \\
\text { West Virginia, USA }\end{array}$ \\
\hline Cytophaga U67 & Cytophaga medium & 25 & $\begin{array}{l}\text { H. Berg, Harvard University, MA, USA } \\
\text { (Lapidus \& Berg, 1982) }\end{array}$ \\
\hline Pseudomonas aeruginosa & L-medium & 37 & ATCC 27853 \\
\hline Acholeplasma laidlawii & PPLO-medium & 37 & $\begin{array}{l}\text { P. Fernandes, Squibb Institute of Medical Research, } \\
\text { Princeton, NJ, USA }\end{array}$ \\
\hline
\end{tabular}

(1973), who reviewed the EPM of a variety of microorganisms.

Electrophoresis has also been done at the microscopic scale (microelectrophoresis). The general usefulness of microelectrophoresis has been demonstrated in studies on a variety of micro-organisms (Brinton \& Lauffer, 1959). However, the measurements require the timed tracking of individual cells, making the method cumbersome and time consuming. In contrast, the Penkem S3000 electrokinetic analyser is capable of measuring the EPM of larger populations of suspended cells. Since both sample measurement and data acquisition are under computer control, collection of data is rapid and kinetic studies, such as the rate of cell surface changes due to altered growth conditions, virus export or drug interactions, can be done. In this report we demonstrate that under standard culture conditions the EPM of a selected group of Gram-negative and Gram-positive bacteria is negative. The largest contribution to the EPM was generated by capsular antigens and, to a lesser degree, by LPS. The EPM was also affected by extrusion of filamentous virions and by polymyxin $B$.

\section{Methods}

All electrophoretic measurements were performed in a Penkem S3000 electrokinetic analyser described by Goetz (1985). The system is microprocessor-controlled and calculates the mean EPM of suspended particles by measuring their velocity in an applied electric field at the 
stationary level. Typically the $S 3000$ uses 16 polarity reversals to calculate the EPM. Velocity is calculated from the frequency at which laser light, scattered at $90^{\circ}$ from the moving particles, passes through the slits of a grating that is rotated through the path of the scattered light. Absolute EPM histograms and means are calculated by obtaining a power versus frequency spectrum by fast Fourier transformation on the time-domain voltage signal. The $\mathrm{S} 3000$ automatically calculates the mean EPM by identifying the channel with the highest frequency and the three neighbours on each side of it. The relative frequencies in these seven channels are used as an estimate of $100 \%$ of the particle distribution and as the weighting factors for the corresponding channel mobilities to compute an EPM value which describes the particle population. EPM is defined as the ratio of particle velocity (measured in this work as $\mu \mathrm{m} \mathrm{s}^{-1}$ ) to field strength (expressed as $\mathrm{V} \mathrm{cm}^{-1}$ ); thus the units of EPM in this paper are $\mu \mathrm{m} \mathrm{cm} \mathrm{V}^{-1} \mathrm{~s}^{-1}$. In addition to the EPM calculation, the $\mathrm{S} 3000$ plots a mobility histogram to reveal the presence or absence of secondary but significant subpopulations outside the seven channel peak area. Frequency plots represent the entire population measured. Fixed human red blood cells are used to calibrate the $\mathrm{S} 3000$ and to ensure that the coefficient of variation is less than $2 \%$. The conductance of L-medium used in most of the experiments, was $17000 \mathrm{~S} \mathrm{~cm}^{-1}$ with slight variations, except for the high-phosphate and low-phosphate media, which had a conductance of $37500 \mathrm{~S} \mathrm{~cm}^{-1}$.

The bacterial strains, their growth conditions and their origin are shown in Table 1. Bacteria were grown aerobically in their respective media. L-medium was used in most instances, containing, per litre $: 10 \mathrm{~g}$ $\mathrm{NaCl}, 1 \mathrm{~g}$ glucose, $10 \mathrm{~g}$ tryptone, $5 \mathrm{~g}$ yeast extract (Difco). The media were ultrafiltered $(0.2 \mu \mathrm{m}$, Gelman) before use. In most cases, cultures were used at densities of maximally $1 \times 10^{8} \mathrm{cells}^{-1}$ and diluted twoto sixfold immediately before transfer into the electrophoresis chamber; under these conditions between 100 and 200 organisms were visible in the laser-illuminated field of the $\$ 3000$. The chamber temperature was $37^{\circ} \mathrm{C}$ unless stated otherwise. Measurements were usually started 10 to $20 \mathrm{~s}$ after chamber loading. Each measurement was obtained from data generated over approximately $1 \mathrm{~min}$ during eight polarity reversals. For studies of membrane fractions, polystyrene latex beads (sulphated polystyrene, either 1.06 or $0.68 \mu \mathrm{m}$ in diameter, Interfacial Dynamics Corporation) were used in $0.1 \mathrm{M}-\mathrm{NaCl}$. Membrane vesicles from $E$. coli $C S 109$ were prepared in a French press and subsequently subjected to sucrose gradient fractionation, according to Bayer et al. (1982). Representative vesicle fractions $(40 \mu \mathrm{l}, 1 \mathrm{mg}$ protein $\mathrm{ml}^{-1}$ ) were adsorbed onto latex beads diluted in $2 \mathrm{ml} \mathrm{NaCl}(0.1 \mathrm{M})$ so that approximately $10^{2}$ beads were observed in the path of the laser beam within the chamber.

Polymyxin B and the polymyxin B nonapeptide (PMBNP) were purchased from Sigma and used at $10 \mathrm{mg} \mathrm{ml}^{-1}$ and 30 or $300 \mathrm{mg} \mathrm{ml}^{-1}$, respectively. Ampicillin (Sigma) was used at $500 \mu \mathrm{g}$ per ml of culture. Carbonyl cyanide $m$-chlorophenylhydrazone (CCCP; Sigma) was used at final concentration of 2,4 or $20 \mathrm{~mm}$.

\section{Results}

\section{$E$. coli B growth phases and effect of growth medium}

E. coli B, which has rough-type LPS (Prehm et al., 1975), had an EPM of approximately $-1 \cdot 19$ (Table 2 ) Fig. 1 shows a typical histogram of the cell suspension. The cells maintained their electrokinetic behaviour in both the exponential growth phase and the stationary phase (Fig. 2). For this experiment, the cells of each of the cultures were washed once before measurements by sedimentation and resuspension in new filtered L-

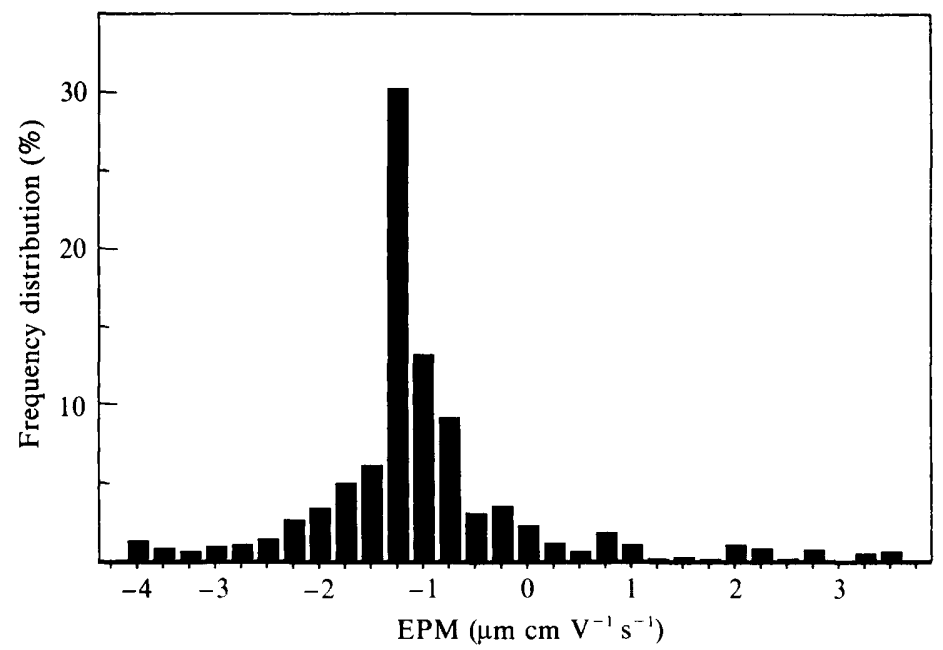

Fig. 1. Histogram showing the EPM of E. coli B growing in L-medium. The majority of cells are present in one (peak) population.

Table 2. EPM of bacterial strains in growth media

\begin{tabular}{lc}
\hline \hline \multicolumn{1}{c}{ Strain } & $\begin{array}{c}\text { EPM } \\
\left(\mu \mathrm{m} \mathrm{cm} \mathrm{V}^{-1} \mathrm{~s}^{-1}\right)\end{array}$ \\
\hline E. coli B & $-1.199 \pm 0.075$ \\
E. coli B + ampicillin $\left(500 \mu \mathrm{g} \mathrm{ml}^{-1}\right)$ & $-1.192 \pm 0.075$ \\
E. coli $\mathrm{B}+$ polymyxin $\left(10 \mathrm{mg} \mathrm{ml}^{-1}\right)$ & $-0.815 \pm 0.120$ \\
E. coli B + PMBNP $\left(30 \mathrm{mg} \mathrm{m}^{-1}\right)$ & $-0.802 \pm 0.071$ \\
E. coli B + PMBNP +CCP & $-0.877 \pm 0.076$ \\
E. coli B high phosphate & $-2.363 \pm 0.015$ \\
E. coli B low phosphate & $-1.886 \pm 0.035$ \\
\hline \hline
\end{tabular}

medium. Growth for $4 \mathrm{~h}$ in media of different phosphate concentrations (Neu \& Heppel, 1965) altered the EPM of $E$. coli B : at low phosphate concentration mean EPM of -1.88 was observed, whereas after cell growth at high phosphate concentrations (0.06 M-potassium phosphate), the EPM was -2.36 (Table 2). Both of these values were higher than the EPM for $E$. coli grown in L-medium.

\section{Effects of O-antigen}

E. coli strains B/1,5, W3110 and CR34 showed similar EPM ranges (Table 3). A significantly reduced (less negative) EPM (-0.839) was observed for GR467, a heptose-less mutant of $E$. coli CR34. S. typhimurium LT2-M1 produces $\mathrm{O}$-antigen in a galactose-containing medium, whereas in glucose medium O-antigen assembly does not occur (Holme et al., 1968). Under both of these conditions the cells showed a comparatively low $\operatorname{EPM}(-0.21$ and -0.20 , respectively), suggesting that the presence or absence of this type of $\mathrm{O}$-antigen does not affect the EPM of $S$. typhimurium. Another example for the absence of an effect of O-antigen on the EPM was 


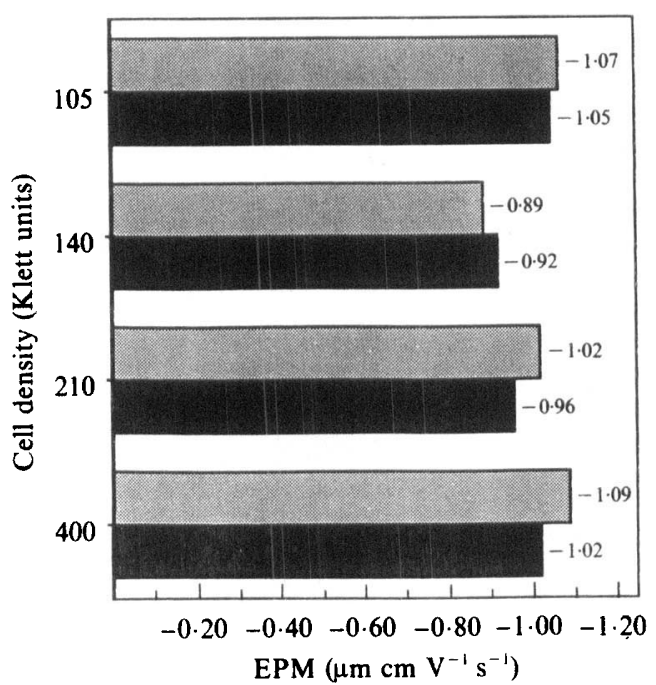

Fig. 2. EMP of $E$. coli B during exponential growth in L-medium at $37^{\circ} \mathrm{C}$ (upper three pairs of columns) and in the stationary phase (lower pair of columns). The turbidity of the cultures is given in Klett units (no. 66 filter; $100 \mathrm{Klett}$ units $\equiv 3 \times 10^{8}$ cells ml $^{-1}$ ). The values given on the graph are those before dilution and measurement. Immediately before measurement, $24 \mathrm{~h}$ stationary-phase cultures were centrifuged and the cells re-dispersed in L-medium, then diluted to match the required turbidity conditions. Cells from growing cultures were treated similarly and diluted before measurement if necessary. In this figure and Fig. 3 the EPM is expressed as mobility $\left(\mu \mathrm{m} \mathrm{s}^{-1}\right)$ divided by electric field strength $\left(\mathrm{V} \mathrm{cm}^{-1}\right)$. Grey and black bars show the results from two separate experiments.

Table 3. EPM of E. coli differing in LPS

\begin{tabular}{lc}
\hline \multicolumn{1}{c}{ Strain } & $\begin{array}{c}\text { EPM } \\
\left(\mu \mathrm{m} \mathrm{cm} \mathrm{V}^{-1} \mathrm{~s}^{-1}\right)\end{array}$ \\
\hline E. coli $\mathrm{B} / 1,5$ & $-1 \cdot 150 \pm 0.135$ \\
E. coli W3110 & $-1 \cdot 143 \pm 0.071$ \\
E. coli CR34 & $-1.005^{*}$ \\
E. coli GR467 & $-0.839 \pm 0.059$ \\
S. typhimurium & \\
LT2-M1 (heated) glucose-grown & $-0.219 \pm 0.050$ \\
LT2-M1 (heated) galactose-grown & $-0.205 \pm 0.084$ \\
\hline \hline
\end{tabular}

* Result obtained from two measurements of EPM.

observed in the uncapsulated mutants of $E$. coli $\mathrm{K} 30$ (Table 4) which revealed similar EPMs in the presence $(-0.53)$ and absence $(-0.51)$ of the 09 -antigen.

\section{Effect of antibiotics}

Ampicillin at a concentration of $500 \mu \mathrm{g} \mathrm{ml}^{-1}$ had no effect on the EPM of $E$. coli B within the measured time period of $15 \mathrm{~min}$ (Table 2). Polymyxin B at $10 \mathrm{mg} \mathrm{ml}^{-1}$ caused a rapid drop of the EPM to -0.815 and it remained at that level for the length of the experiment (up to $19 \mathrm{~min}$ ). Cells treated with PMBNP showed a similar drop to an EPM of -0.802. PMBNP increases
Table 4. EPM of capsulated E. coli $K$ strains and non-capsulated mutants

\begin{tabular}{|c|c|}
\hline Strain & 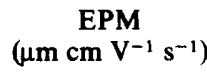 \\
\hline E. coli $\mathrm{K} 1$ (Troy) & $-1.795 \pm 0.007$ \\
\hline E. coli $\mathrm{K} 1$ (Troy) $25^{\circ} \mathrm{C}$, shift to $37^{\circ} \mathrm{C}$ & $-1.821 \pm 0.017$ \\
\hline E. coli K1 (Bort) & $-0.899 \pm 0.097$ \\
\hline $\begin{array}{l}\text { E. coli } \mathrm{K} 1 \text { (Bort) } \\
\text { capsule-negative mutant }\end{array}$ & $-0.238 \pm 0.082$ \\
\hline E. coli $\mathrm{K} 5$ strain, A63; O18:K5 & $-1 \cdot 282 \pm 0.120$ \\
\hline $\begin{array}{l}E \text {. coli } \mathrm{K} 5 \text { strain, A63; O18 } \\
\text { capsule-negative mutant }\end{array}$ & $-0.275 \pm 0.022$ \\
\hline E. coli $\mathrm{K} 5$ strain $357 ; 06: \mathrm{K} 5$ & $-1 \cdot 198 \pm 0.030$ \\
\hline $\begin{array}{r}E \text {. coli } \mathrm{K} 5 \text { strain } 357 ; \mathrm{O} 6 \\
\text { capsule-negative mutant }\end{array}$ & $-0.312 \pm 0.015$ \\
\hline E. coli $09: \mathrm{K} 29$ & $-1.329 \pm 0.110$ \\
\hline $\begin{array}{l}\text { E. coli } 09 \text {; capsule } \\
\text { K29-negative mutant }\end{array}$ & $-0.566 \pm 0.007$ \\
\hline E. coli O9: K29 ts capsule mutant M41 & $-0.719^{*}$ \\
\hline E. coli $\mathrm{O} 9: \mathrm{K} 29$ ts capsule mutant $\mathrm{M} 13$ & $-1 \cdot 410^{*}$ \\
\hline E. coli $\mathrm{K} 30$ strain; $09: \mathrm{K} 30$ & $-1 \cdot 190^{*}$ \\
\hline $\begin{array}{l}\text { E. coli } \mathrm{K} 30 \text { strain; } \mathrm{O} 9 \\
\text { capsule-negative mutant }\end{array}$ & $-0.533^{*}$ \\
\hline $\begin{array}{l}E \text {. coli } \mathrm{K} 30 \text { strain; O9-megative and } \\
\text { capsule K } 30 \text {-negative }\end{array}$ & $-0.516^{*}$ \\
\hline
\end{tabular}

* Results obtained from two measurements of EPM.

permeability without exerting the bactericidal activity of the complete molecule of polymyxin B (Vara \& Vara, 1983). We used PMBNP in an attempt to gain access to the periplasm; we also combined PMBNP with ampicillin to disturb the peptidoglycan structure. However, the timed combinations of ampicillin, PMBNP and subsequent CCCP treatment were without significant effect on the EPM, which appeared to remain affected only by the positive charge of the nonapeptide (PMBNP).

\section{Effect of capsulation}

The following experiments demonstrate that polysaccharide capsules provide the bacteria with a negative charge stronger than that of LPS and surface-associated proteins. As described above, we studied the capsulated $E$. coli strains at neutral $\mathrm{pH}$ in their growth medium (Table 4, Fig. 3). E. coli $\mathrm{K} 1$ (Troy) grown at two temperatures $\left(25^{\circ} \mathrm{C}\right.$ and $\left.37^{\circ} \mathrm{C}\right)$ showed similar EPM values $(-1.79$ and -1.82 , respectively). These represent the highest negative charges of all the strains measured. Consistently, E. coli K1 (Bort) revealed a lesser charge. The two capsulated $E$. coli $\mathrm{K} 5$ strains showed EPMs of -1.28 and -1.19 ; again, the $\mathrm{O}$-antigens (O18 and $\mathrm{O}$ ) of uncapsulated $\mathrm{K} 5$ mutants contributed less to the net charge than the capsular antigen (Table 4). Capsulated $E$. coli K29 of LPS-type O9 followed the same pattern. The primary structure of the capsular polysaccharide of $E$. coli $\mathrm{K} 29$ contains two negative charges per subunit: one from glucuronic acid and one from pyruvate (Fehmel et al., 1975). In contrast, the capsule polysaccharide of 


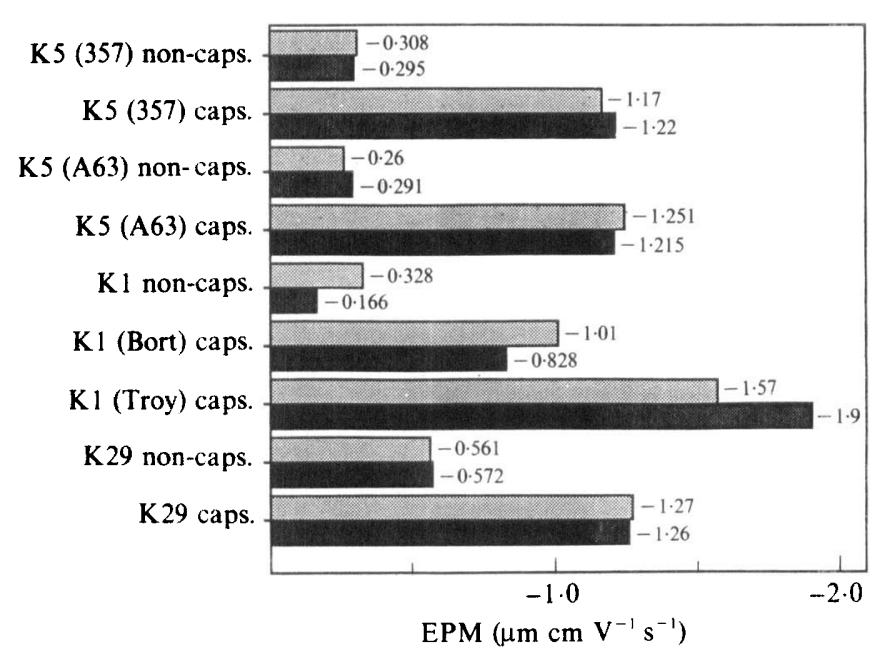

Fig. 3. EPM of capsulated E. coli strains and their non-capsulated mutants. Grey and black bars show the results from two separate experiments.

Table 5. Effect of f1 bacteriophage infection on the EPM of E. coli

\begin{tabular}{|c|c|c|c|}
\hline Strain & $\begin{array}{c}f 1 \\
\text { Infection }\end{array}$ & $\begin{array}{l}\text { Incubation } \\
\text { after infection }\end{array}$ & 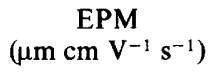 \\
\hline A95 & - & - & $-0.770 \pm 0.088$ \\
\hline A96 & - & - & $-0.592 \pm 0.092$ \\
\hline A96 & + & $20 \mathrm{~min}$ at $31^{\circ} \mathrm{C}$ & $-0.773 \pm 0.037$ \\
\hline A96 & + & $40 \mathrm{~min}$ at $31^{\circ} \mathrm{C}$ & $-0.778 \pm 0.036$ \\
\hline A95 & + & $55 \mathrm{~min}$ at $41^{\circ} \mathrm{C}$ & $-0.858 \pm 0.035$ \\
\hline A95 & + & $\begin{array}{c}55 \text { min at } 41{ }^{\circ} \mathrm{C} \text {, then } \\
40 \text { min at } 34^{\circ} \mathrm{C}\end{array}$ & $-1 \cdot 190 \pm 0 \cdot 150$ \\
\hline
\end{tabular}

Table 6. EPM of Pseudomonas aeruginosa, Cytophaga U67, Gram-positive bacteria, $E$. coli envelope fractions and latex beads

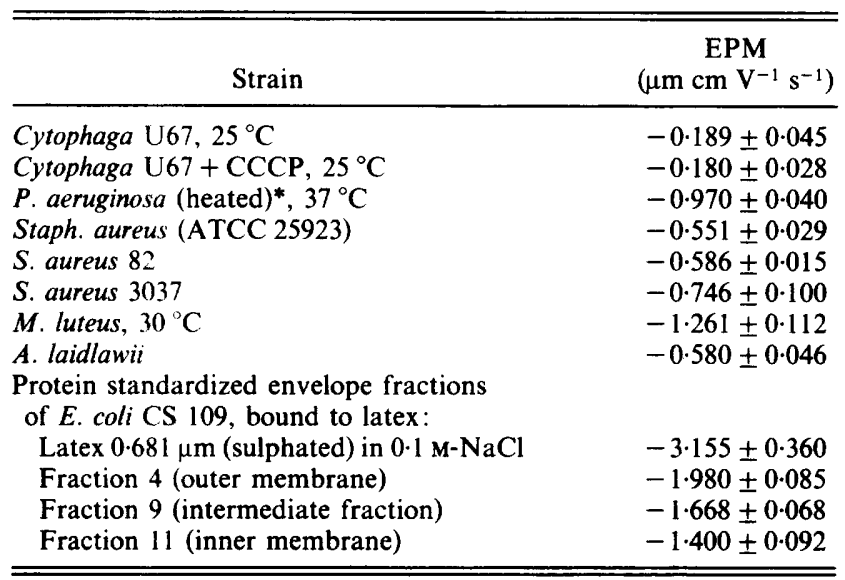

* P. aeruginosa $(0.5 \mathrm{ml})$ was heated at $70^{\circ} \mathrm{C}$ for 60 to $80 \mathrm{~s}$ to eliminate flagellar motion.
K30 lacks the pyruvate, but contains one glucuronic acid (the LPS of both cell strains is O9-specific). The EPM of $\mathrm{K} 30$ is considerably lower than that of K29 (Table 4). The presence of the $\mathrm{O} 9$ side-chain, a mannose pentasaccharide (Prehm et al., 1975), does not affect the EPM of the O9-negative mutants. The temperature-sensitive capsule K29 mutant M13 (Bayer \& Thurow, 1977) had an EPM of -1.41 , which is similar to that of wild-type K29, whereas the M41 mutant strain had a lower EPM of -0.71 . Since both mutants, under permissive conditions, export capsular antigen of $\mathrm{K} 29$ specificity, the interpretation of these differences has to await further experimentation.

\section{Effect of protein export; phage f1}

We studied the effect of extrusion of filamentous phage from the surface of infected cells. E. coli A95 and A96 are hosts for the filamentous phage fl (Russell \& Model, 1983). The mean EPM of uninfected cells was -0.77 for strain A95 and -0.59 for strain A96 (Table 5). When A96 was infected with bacteriophage f1 (multiplicity of infection $=10$ ), the mean EPM of the cells increased within $20 \mathrm{~min}\left(\right.$ at $31{ }^{\circ} \mathrm{C}$ ) to -0.77 and remained at that level $40 \mathrm{~min}$ after infection. Phage $\mathrm{f} 1$ production in strain A95 is temperature-sensitive and is blocked at $41^{\circ} \mathrm{C}$. When A95 was infected with $\mathrm{f} 1$ phage $(5 \mathrm{~min}$ at $31{ }^{\circ} \mathrm{C}$ ) and switched to $41^{\circ} \mathrm{C}$ for $55 \mathrm{~min}$, the cells still showed a high EPM $(-0.858)$, similar to the infected cells grown at $31^{\circ} \mathrm{C}$. However, in the electron microscope, most of the (negatively stained) cells did not reveal phage particles in association with the cell surface, and very few unattached phages were observed in the background of the specimen. The few percent of cells that had phages attached showed only one to five phages in contact with their surface. When such cultures were down-shifted to $34{ }^{\circ} \mathrm{C}$, then grown at the permissive temperature for $40 \mathrm{~min}$ and briefly centrifuged and resuspended to remove free phages, a relatively high EPM (-1.19) was observed, and electron microscopy showed a large number (more than 50) of filaments per cell, with almost all cells involved in filament production. The filaments represented phages since the cells agglutinated within seconds with fl-specific antibody. In contrast, when the infected cultures of the same temperature-sensitive strain were grown at $41^{\circ} \mathrm{C}$, they agglutinated only after 5 min exposure to the antibody. We conclude that the increased EPM of the infected cells is largely caused by the extrusion of the filamentous phage.

\section{Other bacterial strains}

The EPM of bacterial strains other than Gram-negative Enterobacteriaceae growing in the appropriate growth medium and temperature was studied (Table 6). Cyto- 
phaga U67 is a freshwater bacterium whose gliding activity has been studied in detail (Lapidus \& Berg, 1982). The organism exhibits the major ultrastructural features of Gram-negative enterobacteria. Its required growth medium had a low ionic strength with a conductance of $290 \mathrm{~S} \mathrm{~cm}^{-1}$. U67 showed an EPM of $-0 \cdot 189$. Since the EPM increases with diminishing conductance, the measured EPM indicates a very low net charge of the organism. Treatment of the actively gliding organisms with 4 to $20 \mathrm{~mm}-\mathrm{CCCP}$, which dissipates the proton gradient of the inner membrane and stops the directional gliding activity of U67, had no significant effect on the EPM (Table 6). A. laidlawii, an organism lacking a cell wall, was grown (in the absence of sucrose) in PPLO broth, a medium of relatively high conductivity $\left(28700 \mathrm{~S} \mathrm{~cm}^{-1}\right)$. The cells showed an EPM of -0.58 . Decreasing the ionic strength of the PPLO medium to that of L-medium resulted in lysis of the cells. Treatment of the cells with either 2 or $4 \mathrm{mM}-\mathrm{CCCP}$ or metabolic poisons ( $\mathrm{KCN}$, sodium arsenite) produced no significant change in the EPM (data not shown).

\section{EPM of cell membrane fractions}

Membrane fractions from E. coli CS 109 were used to explore whether they exhibit charge differences distinguishable by the analyser. The relatively small size of the membrane 'vesicles' prohibited their direct measurement as light-scattering objects. However, when they were adsorbed to sulphated latex beads $(0.681 \mu \mathrm{m}$ in diameter, in $0 \cdot 1 \mathrm{M}-\mathrm{NaCl}$ ) characteristic changes in the beads' own charge $(-3.155)$ were observed for each group of added membrane fractions (Table 6): the outermembrane fraction showed an EPM of -1.98 , whereas that of the inner membrane was -1.400 , with the fractions of intermediate density generating an EPM of intermediate value $(-1.668)$. These data were collected from seven runs for each fraction.

\section{Discussion}

The complexity of bacterial surfaces makes predictions relative to biophysical parameters, such as surface charges, difficult. A central role for the surface charge in interactions with other cells and for microcolony formation has been proposed by Allison \& Sutherland (1987). The attachment of cells to solid surfaces was found to be facilitated by divalent cations as well as by polysaccharides at the cell surface (Fletcher \& Floodgate, 1976). Electron microscopic and virological data (Bayer et al., 1979, 1986) have been used to describe the bacterial surface, especially that of capsulated cells; these data support the model of a cell surface functioning as a porous double layer (Lyklema, 1985) in which the macromolecules throughout the depth of the capsules exhibit their biological activity and reveal their (covalently bound) anionic charges. In agreement with this concept are electron microscopic data that show cationic ferritin having access to the entire depth of the capsular domain (Bayer, 1990). However, depth and porosity of cell surface layers may vary considerably when one compares, for example, the relatively tight structures of Gram-positive cell walls with the highly hydrated polysaccharide capsules of Gram-negative bacteria containing more than $95 \%$ water (Sutherland, 1977). Capsules are of special interest here, since they, and the LPS, have been shown to exert a shielding effect towards macromolecular attack by phages and colicins (van der Ley et al., 1986; Bernheimer \& Tiraby, 1976). Since polysaccharide capsules as well as portions of the LPS are negatively charged at neutral $\mathrm{pH}$, a molecule advancing toward the membranes of the microbial envelope will encounter a gradient of increasing electrostatic charges; furthermore, rising steric hindrances by the tightening macromolecular fabric will affect the mobility of larger molecules as they approach the outer membrane.

Polymers composing bacterial surfaces contain dissociable groups such as carboxyl, phosphate, sulphate or amino groups. Since most cell surfaces contain both basic and acidic groups, the surface is amphoteric, with a negative net charge at high $\mathrm{pH}$ and a positive charge at low $\mathrm{pH}$. At a certain $\mathrm{pH}$, the net charge of a surface will approach zero. The relation of this point to the isoelectric point is discussed by Lyklema (1985). Together with counter-ions from the adjacent liquid medium, the charged surface biopolymer will generate an electric double layer. A variety of such layers has been described in several models (James et al., 1978; Lyklema, 1985). It is evident from these models that in addition to being strongly affected by the cross-sectional profile of the biopolymer, the charge gradient and the net electrokinetic potential of a cell surface depend also on the $\mathrm{pH}$, the ionic strength and the composition of the environment. The present set of data was obtained with bacteria growing at neutral $\mathrm{pH}$ in liquid culture, conditions which entail a relatively high ionic concentration and therefore a reduced sensitivity. We preferred these conditions over measurements in distilled water or buffers of low ionic strength which are prone to induce swelling of cells, release of surface components and DNA and which may cause cell lysis. Lysis with a concomitant increase in the EPM was already evident in our preparations of $E$. coli treated with penicillin and was also seen in Acholeplasma exposed to L-medium; Acholeplasma cells lysed rapidly in $\mathrm{H}_{2} \mathrm{O}$. The interdependence of surface free energies, zeta potential and elemental compositions has been shown for oral streptococci (Van der Mei et al., 1988) and 
for yeast and bacteria (Mozes et al., 1988). Our data revealed that at neutral $\mathrm{pH}$ of the medium the net charge was negative for all strains tested, with the magnitude of the charge varying widely. The lowest value was found for Cytophaga U67. The highest charges were observed for polysaccharide capsules, especially for the neuraminic acid capsule of $E$. coli $\mathrm{K} 1$. A high EPM was also found for $E$. coli B (a non-capsulated strain) grown in high-phosphate medium. $E$. coli strains studied by microelectrophoresis have been reported to have a mobility of up to -2.9 (Brinton \& Lauffer, 1959). This relatively high value can be explained by the lower ionic strength of buffer compared to that of L-medium used in our experiments. According to Mozes et al. (1988), the major determinants of the negative surface charge are phosphate groups, a view that may also apply for our data concerning the rough strains of $E$. coli, such as $E$. coli B and CR34 (Table 3). However, these authors also point out that the presence of 'nitrogenous functions' on a membrane surface would decrease the negative charge. Cell strains starting to synthesize an electroneutral oligosaccharide, such as the $\mathrm{O} 9$ antigen, do not acquire additional charges. This is demonstrated in the O9positive and O9-negative mutants of K30 (Table 4) and in the galactose-dependent $\mathrm{O}$-antigen of $S$. typhimurium (Table 3). It is noteworthy that the net charge of E. coli B did not change at different stages of growth or in the stationary phase. This is in disagreement with electrophoretic measurements by Moyer (1936), who found in $E$. coli a decrease of the EPM by $20 \%$ within $1 \mathrm{~h}$ of growth and an increase when the culture re-entered the lag phase. We have not observed in any of our E. coli B cultures significant differences between the EPMs of growing and stationary cells. We have no explanation for this observation and assume it to be the result of differences in experimental procedures. Each data point of the $\mathrm{S} 3000$ is the result of several hundred measurements within a few seconds. The EPM also did not change when we replaced our procedure of centrifugation and pellet resuspension with a simple 4-10 $\times$ dilution of the original culture, to reduce artifact formation due to the washing process (Brinton \& Lauffer, 1959).

An electrokinetic effect of charge-providing groups in the cell's capsule is suggested by the result that the deletion of a pyruvate from the subunit of a capsule of type K29 appears to reduce the electronegativity of a capsule containing a carboxyl as sole charge-promoting group, such as the $\mathrm{K} 30$ capsule. We found the highest EPMs in capsulated cells, and we propose, therefore, that the enterobacterial polysaccharide capsule makes a major contribution to the net surface charge. The concept of a porous double layer (Lyklema, 1985) appears to be best suited to describe the property of capsules; it allows one to interpret some of the differences encountered in the EPM of similar strains (for example K1). Light microscopy shows that the thickness of the capsule may vary considerably among growing cells (Bayer, 1990). Since the thickness of the capsule appears to be determined by the length of its polysaccharide fibres, variations in length of the individual fibres may be the cause of the variations in the size of the capsules in a given cell population. Assuming a constant area density of fibres around the cell and an identical composition and exposure of subunits within a polysaccharide fibre, the number of covalent charges will vary in proportion to fibre length or capsule thickness. Due to the highly porous character of capsules, their net charge may therefore be affected by their thickness.

We observed changes in the electrokinetic behaviour of cells that extrude filamentous virions (Table 5). Since studies of the lipid and phospholipid content of $E$. coli producing filamentous phage $\mathrm{fl}$ did not reveal major compositional changes in the outer membrane (Bayer \& Bayer, 1986), the increased negative charge of the phageproducing host cell appears to be caused by the charge of bacteriophage $\mathrm{f} 1$ particles, as they are being extruded through the envelope.

Among the Gram-positive organisms measured (Table 6), M. luteus ( $M$. leisodeikticus) had the highest electrophoretic mobility $(-1 \cdot 26)$. Induction of lysis by addition of lysozyme increased the mobility to $-2 \cdot 73$, a value that was found in $E$. coli B lysing after T4 phage infection (Sloyer \& Bayer, 1990). We assign most of this increase to the charge of DNA extruding from the cells. The use of the Penkem analyser for the study of particles smaller than bacteria, such as cell membrane fractions, is hampered by their low light-scattering capability. However, the scattering power can be enhanced by adsorption of the particles to latex beads. When sulphated latex beads with an EPM of -3.15 (in $0.1 \mathrm{M}-\mathrm{NaCl}$ ) were exposed to dialysed membrane fractions $(18 \mu \mathrm{g}$ protein $\mathrm{ml}^{-1}$ ) of $E$. coli, a significant charge difference between fractions of outer membrane, intermediate fraction and inner membrane was observed (Table 6): latex beads with fractions of the outer membrane showed the highest negative charge whereas those of the inner membrane generated the lowest charge of the gradient material. The results obtained at protein concentrations of 18 to $20 \mu \mathrm{g} \mathrm{ml}^{-1}$ indicate the high sensitivity of the method. In conclusion the method has been shown to be useful for the study of cell surface charges and of interactions between macromolecules and cells or artificial surfaces. Such data are also essential for the design of chromatographic and gel-electrophoretic separation procedures.

The work was supported by grants RR-05539 and DCB-85-03684 (NSF) to M.E.B. and by CA-06927 (NIH) and an appropriation from the Commonwealth of Pennsylvania to the Cancer Center. We thank Drs W. Cramer, A. Cross, P. Fernandes, N. Georgopapadakou, K. and 
B. Jann, G. Shockman and F. A. Troy for providing us with strains. We also wish to thank Ms K. Trush for the graphics, and Ms M. Piatek for typing the manuscript.

\section{References}

Allison, D. G. \& Sutherland, I. W. (1987). The role of exopolysaccharides in adhesion of freshwater bacteria. Journal of General Microbiology 133, 1319-1327.

BAYER, M. E. (1990). Visualization of the bacterial polysaccharide capsule. In Current Topics in Microbiology and Immunology, vol. 150, pp. 129-157. Edited by K. Jann \& B. Jann. Heidelberg: SpringerVerlag (in the Press).

BAYER, M. E. \& BAYER, M. H. (1986). Effects of bacteriophage fd infection on Escherichia coli HB11 envelope: a morphological and biochemical study. Journal of Virology 57, 258-266.

BAYER, M. E. \& Thurow, H. (1977). Polysaccharide capsule of E. coli : microscope study of its size, structure and sites of synthesis. Journal of Bacteriology 130, 911-936.

Bayer, M. E., Thurow, H. \& BAYER, M. H. (1979). Penetration of the polysaccharide capsule of Escherichia coli (Bil62/42) by bacteriophage K29. Virology 94, 95-118.

Bayer, M. H., Costello, G. \& Bayer, M. E. (1982). Isolation and partial characterization of membrane vesicles carrying markers of membrane adhesion site. Journal of Bacteriology 149, 758-767.

Bernheimer, H. P. \& Tiraby, J.-G. (1976). Inhibition of phage infection by pneumococcus capsule. Virology 73, 308-309.

BRINTON, C. \& LAUfFER, M. (1959). The electrophoresis of viruses, bacteria and cells, and the microscope method of electrophoresis. In Electrophoresis, 10, pp. 427-492. Edited by M. Bier. New York: Academic Press.

Fehmel, F., Feige, U., Niemann, H. \& Stirm, S. (1975). Escherichia coli bacteriophages. Journal of Virology 16, 591-601.

FLeTCHER, M. \& FloOdGate, G. D. (1976). The adhesion of bacteria to solid surfaces. In Microbial Ultrastructure: the Use of the Electron Microscope, pp. 101-107. Edited by R. Fuller \& D. Lovelock. London: Academic Press.

GoEtz, P. (1985). Electrophoresis. In Proceedings of the International Meeting, Rostock, German Democratic Republic, pp. 445-461. Edited by W. Schutt \& H. Klinkmann. Berlin: Walter de Gruyter.

Holme, T., Lindberg, A. A., Garegg, P. J. \& OnN, T. (1968). Chemical composition of cell wall polysaccharide of rough mutants of Salmonella typhimurium. Journal of General Microbiology 52, 45-54.

JAMES, R. O., DAVIS, J. A. \& LECKIE, J. O. (1978). Computer simulation of the conductometric and potentiometric titrations of the surface groups on ionizable latexes. Journal of Colloid and Interface Science 65, 331-344.
KoplOW, J. \& GOLDFINE, H. (1974). Alterations in the outer membrane of the cell envelope of heptose-deficient mutants of Escherichia coli. Journal of Bacteriology 117, 527-543.

LAPIDUS, I. R. \& BERG, H. C. (1982). Gliding motility of Cytophaga sp. strain U67. Journal of Bacteriology 151, 384-398.

VAN DER LEY, P., DE GRAAFF, P. \& ThOMMASSEN, J. (1986). Shielding of Escherichia coli outer membrane proteins as receptors for bacteriophages and colicins by $\mathrm{O}$-antigenic chains of lipopolysaccharide. Journal of Bacteriology 168, 449-451.

LunN, C. A. \& PIGIET, V. (1982). E. coli W3110. Localization of thioredoxin from Escherichia coli in an osmotically sensitive compartment. Journal of Biological Chemistry 257, 11424-11430.

LYKLEMA, J. (1985). Interfacial electrochemistry of surfaces with biomedical relevance. In Surface and Interfacial Aspects of Biomedical Polymers, pp. 293-336. Edited by J. D. Andrade. New York: Plenum Press.

Magnusson, E.-E. \& Bayer, M. E. (1982). Anionic sites on the envelope of Salmonella typhimurium mapped with cationized ferritin. Cell Biophysics 4, 163-175.

MOYER, L. S. (1936). Changes in the electrokinetic potential of bacteria at various phases of the culture cycle. Journal of Bacteriology 32, 433464.

Mozes, N., Leonard, A. J. \& Rouxhet, P. G. (1988). On the relations between the elemental surface composition of yeasts and bacteria and their charge and hydrophobicity. Biochimica et Biophysica Acta 945, 324-334.

Neu, H. C. \& Heppel, L. A. (1965). The release of enzymes from Escherichia coli by osmotic shock and during the formation of spheroplasts. Journal of Biological Chemistry 240, 3685-3692.

Prehm, P., Stirm, S., JanN, B. \& JanN, K. (1975). Cell wall lipopolysaccharide from Escherichia coli B. European Journal of Biochemistry 56, 41-55.

RichmOND, D. V.\& FisHER, D. J. (1973). The electrophoretic mobility of microorganisms. Advances in Microbial Physiology 9, 1-29.

Russell, M. \& MODEL, P. (1983). A bacterial gene, fip, required for filamentous bacteriophage $\mathrm{fl}$ assembly. Journal of Bacteriology 154, 1064-1076.

SLOYER, J. L. \& BAYER, M. E. (1990). Automated electrokinetic analysis: description and application in virology and cell biology. Journal of Virological Methods (in the Press).

SutherLaNd, I. W. (1977). Bacterial exopolysaccharides, their nature and production. In Surface Carbohydrates of the Procaryotic Cell, pp. 27-96. Edited by I. W. Sutherland. London: Academic Press.

Van der Mei, H. C., Leonard, A. J., Weerkamp, A. H., Rouxhet, P. G. \& Busscher, H. J. (1988). Properties of oral streptococci relevant for adherence: zeta potential, surface free energy and elemental composition. Colloids and Surfaces 32, 297-305.

VARA, M. \& VARA, T. (1983). Polycations sensitize enteric bacteria to antibiotics. Antimicrobial Agents and Chemotherapy 24, 107-113. 